\title{
Rediscovery of the rust Diabole cubensis, released as a classical biological control agent against the invasive weed Mimosa pigra in Australia
}

\author{
N. J. Burrows • B. V. Lukitsch • J. R. Liberato
}

Received: 9 January 2012 / Accepted: 7 October 2012 /Published online: 20 October 2012

(C) Australasian Plant Pathology Society Inc. 2012

\begin{abstract}
The neotropical rust Diabole cubensis was introduced as a biological control agent against the weed Mimosa pigra in the Northern Territory during the period 19961999. It was thought to have failed to establish as it had not been observed since then. In 2011, D. cubensis was detected on $M$. pigra plants on the Finniss River and Daly River floodplains, 12 years after its introduction. In 2012, the fungus was also detected on the Mary and Adelaide River floodplains. Details of these findings, a description and illustrations of the rust fungus are included.
\end{abstract}

Keywords Weed Pucciniales

Mimosa pigra L. (Fabaceae), common name mimosa or giant sensitive plant, is a shrub, which can reach a height of 3-6 m, and has as conspicuous characteristic narrowly lanceolate leaflets that fold together when touched or injured and at night (Lonsdale et al. 1989). It is an invasive noxious weed, listed among 100 of the "World's Worst" invaders in the Global Invasive Species Database (http:/www.issg.org/ database/species/ecology.asp? $\mathrm{si}=41 \& \mathrm{fr}=1 \&$ sts $=\mathrm{sss})$.

Mimosa pigra (mimosa) originated from the Neotropics and it is thought to have been introduced to Darwin, Northern Territory, in the late XIX century (Miller and Lonsdale 1987). In the early 1950s a large infestation was discovered at the Adelaide River, about $100 \mathrm{~km}$ south of

N. J. Burrows $(\bowtie) \cdot$ B. V. Lukitsch

Weed Sciences, Department of Land Resource Management, PO Box 496, Palmerston, NT 0831, Australia

e-mail: natasha.burrows@nt.gov.au

J. R. Liberato

Plant Pathology Section,

Department of Primary Industry and Fisheries,

GPO Box 3000, Darwin, NT 0801, Australia
Darwin, and has since spread to the coastal floodplains of some of the main river systems in the Northern Territory. Mimosa plants have adapted to a number of habitats within northern Australia, becoming a serious weed in a wet-dry climate with a minimum of $750 \mathrm{~mm}$ of annual rainfall (Lonsdale et al 1989). Mimosa forms dense, impenetrable monotypic stands, frequently spanning over many thousands of hectares, outcompeting vegetation in sedgeland, riparian, aquatic, paperbark (Melaleuca spp.) and monsoon forest communities (Lonsdale et al 1989).

The Department of Land Resource Management (DLRM), estimates that mimosa has infested 140000 ha of floodplains in the Northern Territory (Boustead 2009). Outside the Northern Territory it has been detected in Proserpine on the central Queensland coast in 2001 (Walden et al. 2004) and in Kununurra, Western Australia in 2009 (Lloyd and Vinnicombe 2010), both areas are being managed for eradication.

A biological control program for $M$. pigra commenced in 1979. Diabole cubensis (Arthur \& J.R. Johnst.) Arthur, an autoecious, microcycle rust, host specific to M. Pigra under field conditions (Seiers 1998), was the eighth biocontrol agent to be introduced. One other fungus Phloeospora mimosae-pigrae H.C. Evans \& G. Carrión was also introduced but failed to establish. From 13 introduced insects, nine have established with varying levels of distribution and effectiveness (Hennecke 2006; Routley and Wirf 2006; Heard et al. 2012).

Diabole cubensis, according to Hennecke (2006), was released at a range of locations in the Northern Territory from 1996 to 1999. The DLRM archived data confirms Hennecke's release localities as follows: two release sites within $3 \mathrm{~km}$ of each other on the Finniss River floodplain; a cluster of releases within a $14 \mathrm{~km}$ radius on the lower Adelaide River floodplain, as well as one other release site 
a further $37 \mathrm{~km}$ up stream on the Adelaide River (Fig. 1). Only one field site on the floodplain of the Finniss River and another on the floodplain of the Adelaide River were chosen for post-release evaluations. Every year, three releases of the fungus were carried out in each of those two sites between June and September. Evaluations on labelled mimosa plants showed that all inoculations were successful, resulting in visible telia on leaves. However at both sites and for the four year period, all mimosa leaves with rust pustules had dropped off within nine weeks after inoculation and no symptoms were observed on neighbouring mimosa plants. Hennecke (2006) then considered that the establishment of $D$. cubensis had failed. Since then, D. cubensis had not been recorded in the Northern Territory.

The DLRM biological control program has included hundreds of release and monitoring sites for multiple biological control agents since 1996, and from 2005, sites across four of the mimosa infested floodplains (Daly River, Finniss River, Adelaide River \& Mary River) have been surveyed on a monthly or bimonthly basis. These surveys did not target $D$. cubensis. In June 2011, whilst monitoring a new agent release site in the Finniss River coastal floodplain, the first two authors observed by chance a very conspicuous rust disease, and then surveyed ten random plants all of them presented rust pustules on up to $33 \%$ of their pinnae. This site had been surveyed for the first time the previous month and the rust disease had not been noticed. It is located on the edge of a dense mimosa patch which is estimated to span over 15000 ha where mimosa plants are up to $6 \mathrm{~m}$ in height and is the dominant understorey within paperbarks. This first site is approximately $36 \mathrm{~km}$ from the closest release site (Fig. 1).

A second site $4 \mathrm{~km}$ from the first site, along the mimosa stand edge was then surveyed specifically for the rust disease in June 2011. Here only one out of ten plants surveyed was found to be infected and its rust incidence on pinnae was $<1 \%$.

Diabole cubensis has since been included as one of the targets of the periodical surveillances with more than 15 sites across the Northern Territory surveyed since its rediscovery.

This fungus has since been identified at a further three sites including one on each of the Daly, Adelaide and Mary River Catchments (Fig. 1). Whilst the rust was very conspicuous when first observed at the site on the Finniss River

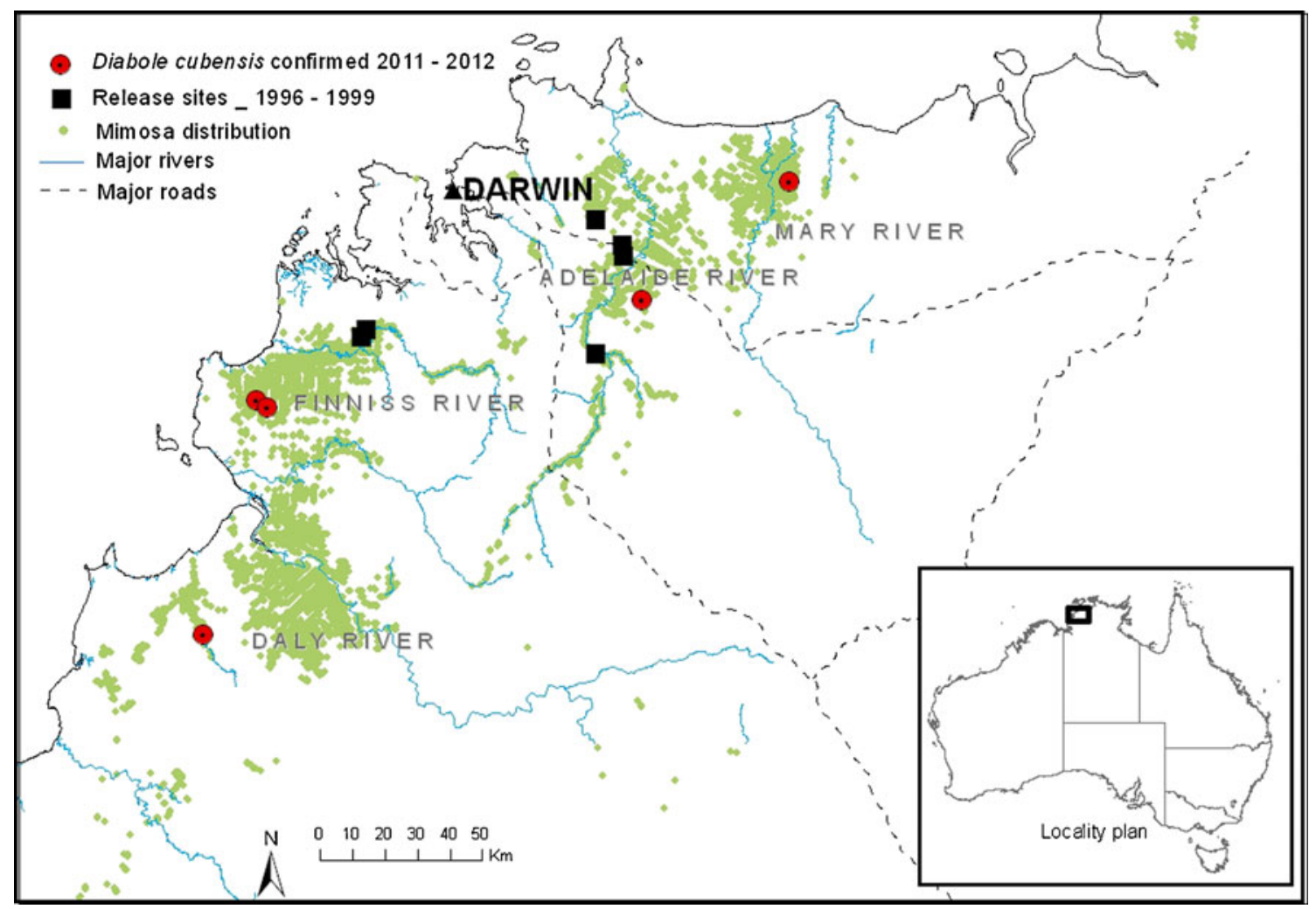

Fig. 1 Distribution of Mimosa pigra in the north of the Daly-Darwin district, Northern Territory (2003), release sites (1996-1999) and rediscovery sites (2011-2012) of Diabole cubensis 
floodplain, it was hard to see at the other sites. In October 2011 D. cubensis was found at a site on the Daly River floodplain, about $100 \mathrm{~km}$ from the nearest Finniss River release site. In June 2012 the rust was found at a site on the Mary River floodplain, $54 \mathrm{~km}$ from the nearest Adelaide River release site. In August 2012 the agent was found at a site on the Adelaide River, $15 \mathrm{~km}$ from a release site. Of the ten plants surveyed each time at each site, on only 1-2 plants were rust pustules observed. The habitat was similar in all of the sites, where mimosa was within or on the edge of paperbark stands.

The rust specimens were examined by mounting spores in lactic acid on microscope slides. The slides were examined with a Leica DM2500 compound microscope using differential interference contrast and images taken with a Leica DFC500 camera. Measurements were obtained only from turgid teliospores from fresh specimens. All five specimens were identified as Diabole cubensis, according to the descriptions provided by Cannon (2007) and Cummins and Hiratsuka (2003). The description of this rust fungus based on these Australian specimens follows.

Diabole cubensis (Arthur \& J.R. Johnst.) Arthur (Figs. 2, 3 and 4)

Bull. Torrey Bot. Club 49: 194 (1922).

$\equiv$ Uromycladium cubense Arthur \& J.R. Johnst., Mem. Torr. Bot. Club 17: 119 (1918).

Spermogonia group VI type 7 (according to Cummins and Hiratsuka's (2003) classification), aggregated, black. Aecia and uredinia were not observed and are unknown for the monospecific genus Diabole. Telia amphigenous, subcuticular, erumpent, scattered, commonly elliptical, chestnut brown, 400-2300 $\times 300-1000 \mu \mathrm{m}$. Teliospores pyriform to somewhat spherical, $17-24 \times 17-24 \mu \mathrm{m}$, verrucose in the top with the basal part smooth, chestnut brown;

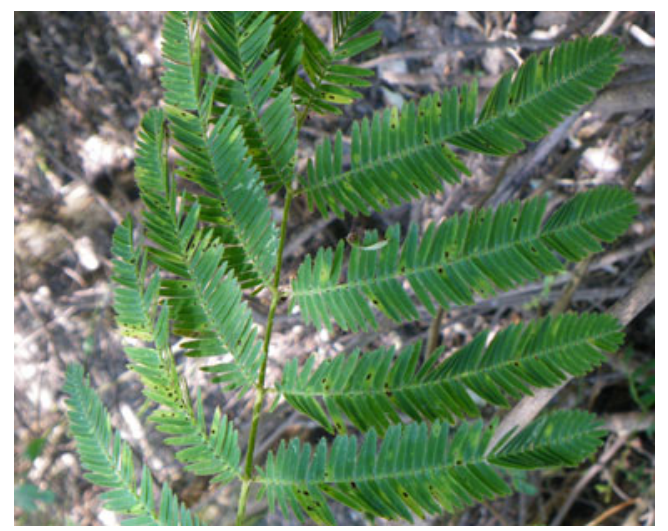

Fig. 2 Symptoms and telia of Diabole cubensis on leaves of Mimosa pigra (Image by B.V. Lukitsch)

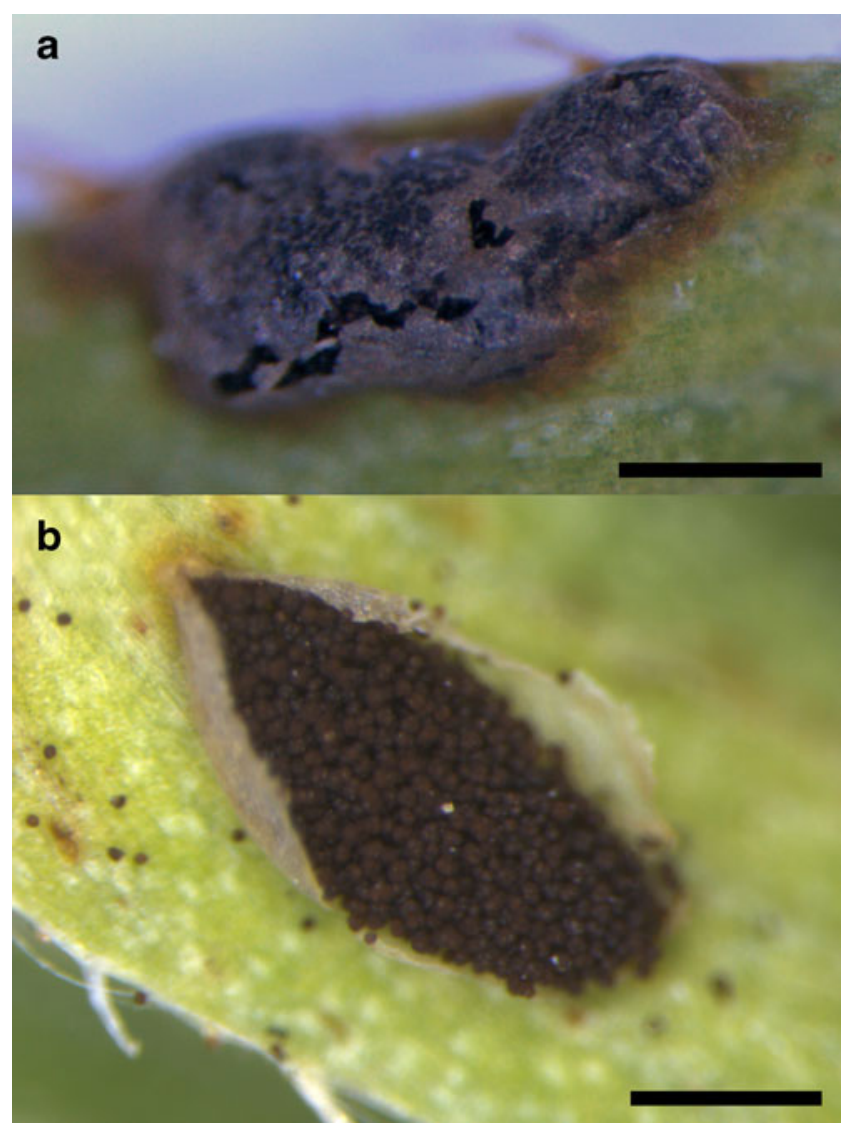

Fig. 3 a-b Telia of Diabole cubensis on Mimosa pigra seen under stereo microscope (DNAP 4667) $($ Bar $=0.5 \mathrm{~mm}$ ) (Images by J.R. Liberato)

pedicels contains $1-3$ cells in the apex, with two paired teliospores attached to each cell. Teliospore wall 1-2 $\mu \mathrm{m}$ thick. Basidia not seen.

Specimens examined on Mimosa pigra: AUSTRALIA, NORTHERN TERRITORY: Finniss River coastal floodplain, Horse Plain, Bulgul Aboriginal Land, $-13.0415^{\circ}$, 130.2959, 17 June 2011, B. Lukitsch and N. Burrows (DNAP 4667), 0, IV; -13.063972 $, 130.32475^{\circ}, 29$ June 2011 (DNAP 4666), 0, IV; Daly River catchment, Mudgut North, $-13.694050^{\circ}, 130.148280^{\circ}, 18$ Oct. $2011, B$. Lukitsch (DNAP 4674), 0, IV; George's Yard Paddock, Mary River floodplain, $-12.438566^{\circ}, 131.769704^{\circ}, 15$ June 2012, B. Lukitsch (DNAP 4684), IV; Snake Creek Station, Adelaide River catchment, $-12.766101^{\circ}$, 131.362286, 7 Aug. 2012, N. Burrows (DNAP 4685), IV.

According to Seier's (1998) studies, teliospore germination occurs between 15 and $30{ }^{\circ} \mathrm{C}$ with optimum between 20 and $25{ }^{\circ} \mathrm{C}$, while higher proportion of basidia and basidiospores, which appear to be the infectious spores, in relation to teliospore germtubes occurs between 15 and $25^{\circ} \mathrm{C}$. When 
Fig. 4 a-d Teliospores of Diabole cubensis. (DNAP 4667) $($ Bars $=10 \mu \mathrm{m})($ Images by J.R. Liberato)
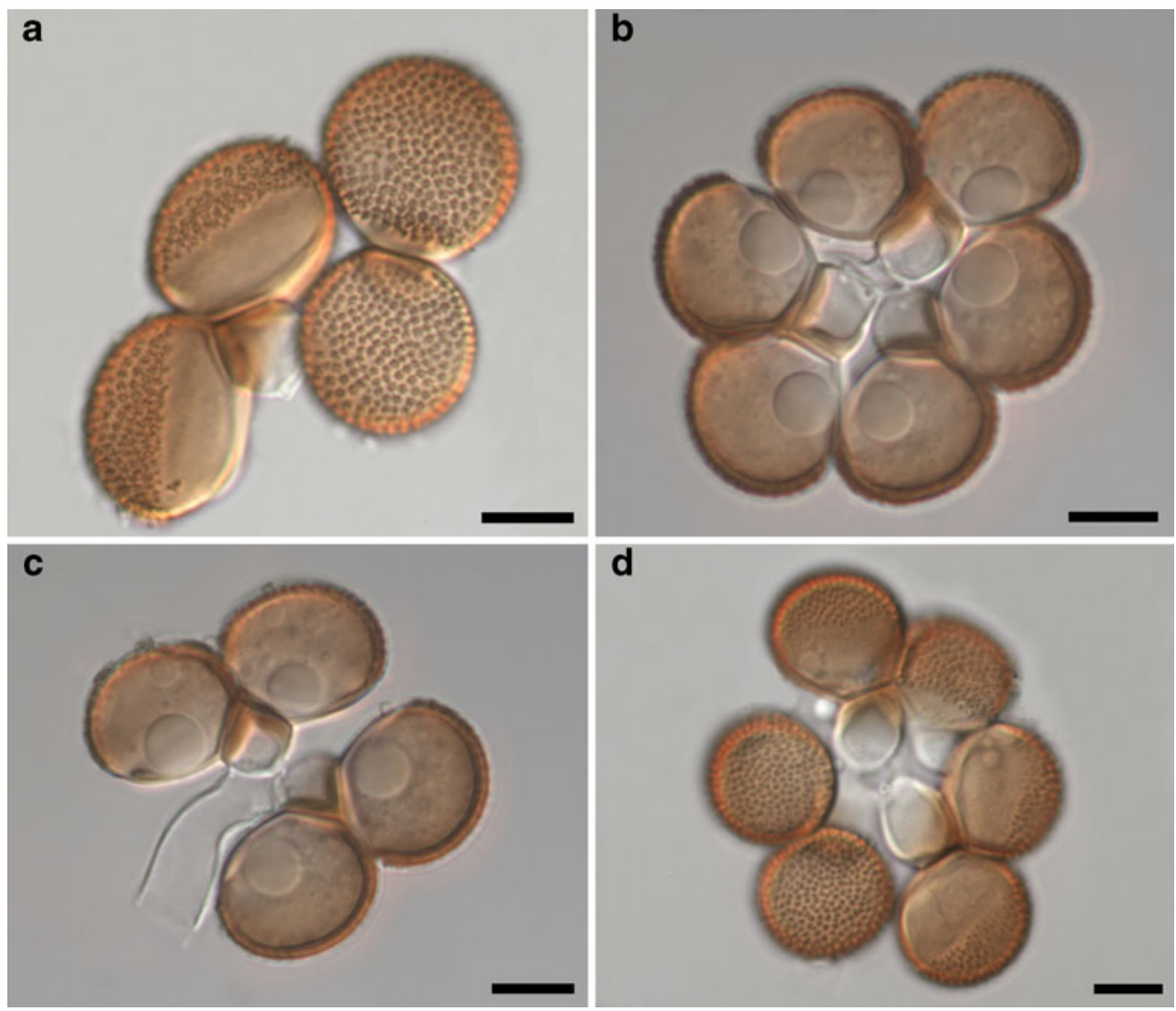

incubated at $21-22{ }^{\circ} \mathrm{C}$, teliospore germination occurs after $2 \mathrm{~h}$ and is close to the peak after $7 \mathrm{~h}$. When inoculated plants are incubated at $21-23{ }^{\circ} \mathrm{C}$, it is necessary to have the presence of free water on the leaflets for a minimum period of $10 \mathrm{~h}$ for infection to occur.

Either the D. cubensis populations detected in 2011 and 2012 are the result of an independent introduction or the population introduced in the late 1990s most likely survived on plants with no post-release evaluation or at undetectable levels. D. cubensis may have survived in favourable microclimate pockets, such as those created by an overstorey of paperbark trees, across the floodplains. The regional climate may be considered not favourable for epidemics of this rust. This is supported by the observations of Evans et al. (1995) describing $D$. cubensis as being absent in the lowland humid tropics of Venezuela, Guyana and Brazil, despite being naturally widespread in tropical areas of Mexico, Central and South Americas (Hennecke 2006). In 2011 the Northern Territory experienced its coldest autumn and the third wettest year on record (BOM 2012). Whilst the rust was rediscovered by chance in July 2011, the favorable weather for the disease in the autumn 2011 may have increased the likelihood.
Acknowledgments The authors would like to acknowledge that the Bulgul Land and Sea Rangers permitted access to land and assisted with field surveys on the Finniss River coastal floodplain. The Yantjarrwu rangers permitted access to the Mudgut North site. Tony Searle, manager of Melaleuca Station, permitted access to the Mary River site and Sam Griffin owner/manager of Snake Creek Station assisted at the Adelaide River site. Dr Bertie Hennecke provided assistance in confirming historical data and further information. The assistance of Territory Natural Resource Management in providing funding for the DLRM field expeditions, under the project, "Enhancing Biocontrol of Mimosa in the Daly, Moyle and Finniss River Catchments", is also gratefully acknowledged.

\section{References}

BOM. Bureau of Meteorology (2012) Annual climate summary 2011. Melbourne, BOM, 24 p. (Available online at http://www.bom. gov.au/climate/annual_sum/annsum.shtml)

Boustead A (2009) Mimosa pigra: national best practice management manual. Northern Territory Government, Palmerston, 65p

Cannon PF (2007) Diabole cubensis. IMI Descriptions of Fungi and Bacteria No 1725, 3p. CAB International, Egham

Cummins GB, Hiratsuka Y (2003) Illustrated genera of rust fungi, 3rd edn. The American Phytopathological Society, St Paul, 225p

Evans HC, Carrion G, Ruiz-Belin F (1995) Mycobiota of the giant sensitive plant, Mimosa pigra sensu lato in the Neotropics. Mycol Res 99(4):420-428 
Heard T, Mira A, Fichera G, Segura R (2012) Nesaecrepida infuscata: a biological control agent of the invasive plant Mimosa pigra. BioControl 57(4):573-580

Hennecke BR (2006) Failure of Diabole cubensis, a promising classical biological control agent, to establish in Australia. Biol Control 39:121-127

Lloyd SG, Vinnicombe TL (2010) Mimosa pigra L, - a new incursion into western Australia. Proceedings of the 17th Australasian Weeds Conference. New Zealand Plant Protection Society, Christchurch, pp 180-181 (available online at http://www.caws.org.au/ awc_index.php)

Lonsdale WM, Miller IL, Forno IW (1989) The biology of Australian weeds 20. Mimosa pigra L. Plant Prot Q 4:119-131

Miller IL, Lonsdale WM (1987) Early records of Mimosa pigra in the Northern Territory. Plant Prot Q 2:140-142
Routley BM, Wirf LA (2006) Advancements in biocontrol of Mimosa pigra in the Northern Territory. Proceedings of the 15th Australasian Weeds Conference. Weed Management Society of South Australia Inc., Adelaide, pp 561-564 (available online at http:// www.caws.org.au/awc index.php)

Seier MK (1998) Evaluation of two fungal pathogens as classical biological control agents of the invasive weed Mimosa pigra in Australia, Von der Gemeinsamen Naturwissenschaftlichen Falkultät. Carolo-Wilhelmina, University of Braunschweig, Germany, $p$ 200

Walden D, van Dam R, Finlayson M, Storrs M, Lowry J, Kriticos D (2004) A risk assessment of the tropical wetland weed Mimosa pigra in northern Australia. Supervising Scientist Report 177, Darwin NT, 66 p. Available online at http://www.environment. gov.au/ssd/publications/ssr/pubs/ssr177-print.pdf 